\title{
DINAMIKA PERTUMBUHAN DAUN BIBIT STEK PUCUK STEVIA MENGGUNAKAN PUPUK KANDANG KOTORAN AYAM PADA TANAH GAMBUT
}

\author{
(The Dynamics of Leaf Growth of Germ of Cutting of the Shoot Stevia \\ (Stevia rebaudiana Bertoni M.) on Using the Chicken Manure Fertilizer in Peat Soin) \\ DJOKO EKO HADI SUSILO
}

Program Studi Agroteknologi Fakultas Pertanian dan Kehutanan

Universitas Muhammadiyah Palangkaraya

JI. RTA Milono Km.1,5 Palangka Raya, Kalimantan Tengah 73111

e-mail : masdjoko_ns@yahoo.co.id

\begin{abstract}
The cultivation of stevia (Stevia rebaudiana Bertoni M.) in peat soil is necessary to find the substitution of sugar needs and as an alternative natural sweeteners. The aim of this study is to know how the the dynamics of leaf growth of germ of cutting of the shoot stevia on using the chicken manure fertilizer in peat soil. The results of this study are expected as a material of the study to support the development of cultivation of Stevia in the peat soil. This study was conducted using a polybag on Wortel street area, Panarung of the District of Pahandut of the Palangka Raya city from April to May 2017. The data of the observation were collected to the leaf growth (number of leaf and leaf area) of germ of cutting of the shoot stevia plant at the age of germ on 10 and 20 days after planting (DAP).

The results of the study showed that the using of chicken manure fertilizer by the dosage 20 tons ha ${ }^{-1}$ until 40 tons ha ${ }^{-1}$ can increasing the dynamics of leaf growth (number of leaf and leaf area) of germ of cutting of the shoot stevia plant at the age of germ on 10 and 20 days after planting (DAP) in peat soil. The result of this study also requires further detailed study on the weight area ratio and spesific leaf area for cutting of the shoot stevia.
\end{abstract}

Keywords: stevia, cutting of the shoot, natural sweetener, sugar, low-calorie sugar, number of leaf, leaf area, chicken manure fertilizer, and peat soil

\section{ABSTRAK}

Budidaya stevia (Stevia rebaudiana Bertoni M.) di tanah gambut dirasa perlu untuk mendapatkan subtitusi kebutuhan gula dan sebagai salah satu alternatif bahan pemanis yang alami. Penelitian ini bertujuan mengetahui dinamika pertumbuhan daun bibit stek pucuk stevia menggunakan pupuk kandang kotoran ayam pada tanah gambut. Hasil penelitian ini diharapkan sebagai bahan kajian dalam mendukung pengembangan budidaya stevia di tanah gambut. Penelitian ini dilaksanakan menggunakan polybag di daerah Jalan Wortel Kelurahan Panarung Kecamatan Pahandut Kota Palangka Raya pada bulan April sampai Mei 2017. Pengamatan dilakukan terhadap pertumbuhan daun (jumlah daun dan luas daun) bibit stek pucuk stevia pada umur bibit 10 dan 20 hari setelah tanam (HST).

Hasil penelitian menunjukkan bahwa pemberian pupuk kandang kotoran ayam dosis 20 ton ha ${ }^{-1}$ sampai 40 ton $\mathrm{ha}^{-1}$ mampu mendukung peningkatan dinamika pertumbuhan daun (jumlah daun dan luas daun) bibit stek pucuk stevia pada umur bibit 10 dan 20 hari setelah tanam (HST) pada tanah gambut. Hasil penelitian juga memerlukan penelitian lanjutan secara detail tentang nisbah berat daun dan luas daun spesifik bibit stek pucuk stevia.

Kata kunci: stevia, stek pucuk, pemanis alami, gula, gula rendah kalori, jumlah daun, luas daun, pupuk kandang kotoran ayam, dan tanah gambut

\section{PENDAHULUAN}

Budidaya stevia (Stevia rebaudiana Bertoni M.) di tanah gambut dirasa perlu sebagai subtitusi kebutuhan gula dan sebagai salah satu alternatif bahan pemanis yang alami di masyarakat Indonesia. Memenuhi kebutuhan pemanis alami di masyarakat sehari-harinya masih dipenuhi dengan mengonsumsi gula pasir dari tebu, namun produksi gula setiap tahunnya hanya mampu memenuhi sekitar 60\% kebutuhan, sehingga harus impor melalui kebijakan pemerintah, termasuk memenuhi pemanis alami dari non tebu 
juga kondisinya masih rendah (Triyatna, 2012). Menteri Perindustrian dan Perdagangan Enggartiasto Lukita menyampaikan bahwa Tahun 2017 produksi gula di Indonesia kapasitasnya hanya sekitar 2,2 juta ton, sedangkan kebutuhan masyarakat mencapai 3,5 juta ton. Untuk itu pemerintah menempuh langkah mengimpor gula sebesar 1,3 juta ton (Ariyanti, 2017; Winarno, 2017).

Pemenuhan kebutuhan gula selain dengan cara impor, juga melalui upaya swasembada gula dengan bentuk revitalisasi sektor on-farm berupa perluasan areal dan peningkatan produktivitas gula, dan revitalisasi sektor off-farm salah satunya berupa pemberdayaan penelitian dan pengembangan gula (Direktorat Jenderal Perkebunan Kementerian Pertanian, 2010). Selain dilakukan produksi gula melalui tebu, maka diperlukan studi potensi produksi pemanis yang dilakukan dari tanaman non tebu yaitu melalui tanaman stevia (Stevia rebaudiana Bertoni M.) yang merupakan alternatif pengganti tebu dalam menghasilkan gula (pemanis) alami. llyas (2003) dan Rukmana (2007) menjelaskan bahwa stevia sebagai sumber pemanis alami non tebu ternyata memiliki keunggulan dibandingkan dengan tebu dengan rasa yang lebih manis dibandingkan tebu karena mengandung senyawa glikosida diterpen dengan tingkat kemanisan mampu mencapai 200-300 kali gula tebu, tetapi pemanis berbahan baku stevia kalorinya lebih rendah dibandingkan gula tebu, serta bersifat non-karsinogenik.

Budidaya tanaman sebagai sumber pemanis alami di Kota Palangka Raya dapat dilakukan menggunakan tanaman stevia yang ditanam di tanah gambut dengan beberapa tindakan perbaikan media tanam tanah gambut dengan meningkatkan kesuburannya. Hal ini terbukti dari beberapa kali stevia dibudidayakan di tanah gambut pertumbuhannya cukup bagus dan media tanah gambut tersebut (Susilo, 2012; Susilo et al., 2012). Budidaya stevia ini juga memanfaatkan potensi penggunaan lahan dikembangkan sebagai lahan budidaya tanaman hortikultura dengan sebaran tanah gambut mencapai $141.088 \mathrm{Ha}$ (BPS, 2010).

Tanah gambut memungkinkan sebagai lahan budidaya, asalkan dilakukan peningkatan kesuburannya. Upaya perbaikan sifat-sifat tanah gambut sebagai media tanam salah satunya bisa dilakukan melalui penambahan pupuk kandang kotoran ayam. Hasil penelitian menunjukkan bahwa pupuk kandang kotoran ayam diberikan pada tanah gambut untuk memperbaiki kesuburannya dalam menunjang pertumbuhan dan hasil tanaman (Atikah, 2004), dan juga terhadap dinamika pertumbuhan tanaman stevia (Susilo et al., 2012).

Kondisi sifat agronomis budidaya stevia yang mudah tumbuh pada tanah yang mengandung bahan organik dan cara perbanyakannya yang sederhana, maka memungkinkan sebagai tanaman alternatif bahan baku pemanis alami. Hal ini diperlukan studi tentang peningkatan pertumbuhan tanaman di saat menyiapkan bibit stevia yang berasal dari stek pucuk dalam mengawali aspek pembudidayaan stevia di tanah gambut melalui kegiatan pembibitan.

Berdasarkan kondisi-kondisi tersebut, maka penelitian ini bertujuan mengetahui dinamika pertumbuhan daun bibit stek pucuk stevia menggunakan pupuk kandang kotoran ayam pada tanah gambut. Hasil penelitian ini diharapkan 
sebagai bahan kajian dalam mendukung pengembangan budidaya stevia di tanah gambut yang memungkinkan dikembangkan di Kota Palangka Raya dalam jangka pendek maupun jangka panjang oleh berbagai pihak.

\section{METODOLOGI}

Penelitian ini dilaksanakan menggunakan polybag di Komplek Fajar Permai 2, Jalan Wortel IV Kelurahan Panarung Kecamatan Pahandut Kota Palangka Raya pada bulan April sampai Mei 2017. Bahan yang digunakan pada penelitian ini yaitu bibit stek pucuk stevia, pupuk kandang kotoran ayam, tanah gambut dan kapur dolomit. Alat yang digunakan adalah polybag kecil, gunting stek, gelas penyiram, kamera digital, plastik milimeter blok, neraca analitik, penggaris, meteran, kalkulator, alat tulis, dan komputer.

Penelitian ini melakukan percobaan pembibitan stek pucuk stevia dengan perlakuan pupuk kandang kotoran ayam dengan dosis 20 ton ha ${ }^{-1}\left(\mathrm{P}_{1}\right) ; 30$ ton ha ${ }^{-1}\left(\mathrm{P}_{2}\right)$; dan 40 ton ha ${ }^{-1}$ $\left(P_{3}\right)$. Masing-masing perlakuan diulang sebanyak 50 kali, sehingga seluruhnya terdapat 150 bibit stek pucuk stevia yang dipelihara dalam penelitian ini. Bibit stevia yang ditanam adalah stek pucuk stevia dengan ukuran 3 ruas ujung (dengan jumlah daun stek 6 daun pada masing-masing stek). Bibit stek pucuk stevia dipelihara dan diamati selama 20 hari setelah tanam. Pengamatan dilakukan terhadap dinamika penambahan pertumbuhan daun yaitu penambahan jumlah daun dan luas daun bibit stek pucuk stevia yang telah tumbuh pada umur 10 sampai 20 HST.

\section{HASIL DAN PEMBAHASAN}

\section{Hasil Pengamatan}

Hasil pengamatan berupa pertumbuhan penambahan jumlah daun dan luas daun stek pucuk bibit stevia menggunakan pupuk kandang kotoran ayam pada tanah gambut Kota Palangka Raya akibat pemberian pupuk kandang kotoran ayam disajikan pada Tabel 1 dan 2. Sedangkan pertumbuhan secara fisik jumlah daun dan luas daun stek pucuk bibit stevia disajikan pada Gambar 1, 2, 3, dan 4.

\section{Pembahasan}

Berdasarkan Tabel 1 dan 2 menunjukkan bahwa pemberian pupuk kandang kotoran ayam mulai dosis 20 ton ha ${ }^{-1}$ sampai 40 ton ha ${ }^{-1}$ terlihat menggambarkan adanya dukungan terhadap pertumbuhan stek dan daun bibit stek pucuk stevia dalam bentuk pertumbuhan stek. Apabila dicermati dinamikanya, maka dengan semakin meningkatnya umur bibit sampai 10 dan 20 HST maka semakin bertambah jumlah daun bibit stek pucuk stevia yaitu selama 10 hari ditanam maka bertambah jumlah daunnya mencapai 2,24 sampai 3,39 daun per bibit sehingga jumlah daunnya dari semula 6 daun per stek awal ditanam menjadi antara 8,24 sampai 9,39 daun per bibit akibat pemberian pupuk kandang di tanah gambut. Begitu juga saat bibit mencapai umur 20 HST maka juga terjadi penambahan kembali jumlah daun bibit mencapai 2,58 sampai 3,42 daun per bibit sehingga jumlah daunnya menjadi antara 10,83 sampai 12,81 daun per bibit akibat pemberian pupuk kandang di tanah gambut. 
Tabel 1. Rata-rata pertumbuhan penambahan daun stek pucuk bibit stevia menggunakan pupuk kandang kotoran ayam pada tanah gambut

\begin{tabular}{|c|c|c|c|c|}
\hline \multirow{3}{*}{$\begin{array}{l}\text { Pupuk Kandang } \\
\text { Kotoran Ayam }\end{array}$} & \multicolumn{4}{|c|}{ Dinamika Pertumbuhan Daun Bibit (helai daun) } \\
\hline & \multicolumn{2}{|c|}{ Bibit Umur 0-10 HST } & \multicolumn{2}{|c|}{ Bibit Umur 10-20 HST } \\
\hline & Penambahan Daun & Jumlah Daun & Penambahan Daun & Jumlah Daun \\
\hline $\mathrm{P}_{1}\left(20\right.$ ton $\left.\mathrm{ha}^{-1}\right)$ & 2,24 & 8,24 & 2,58 & 10,83 \\
\hline $\mathrm{P}_{2}\left(30\right.$ ton $\left.\mathrm{ha}^{-1}\right)$ & 2,69 & 8,69 & 3,23 & 11,92 \\
\hline $\mathrm{P}_{3}\left(40\right.$ ton $\left.\mathrm{ha}^{-1}\right)$ & 3,39 & 9,39 & 3,42 & 12,81 \\
\hline
\end{tabular}

Tabel 2. Rata-rata pertumbuhan penambahan luas daun stek pucuk bibit stevia menggunakan pupuk kandang kotoran ayam pada tanah gambut

\begin{tabular}{|c|c|c|c|c|}
\hline \multirow{3}{*}{$\begin{array}{l}\text { Pupuk Kandang } \\
\text { Kotoran Ayam }\end{array}$} & \multicolumn{4}{|c|}{ Dinamika Pertumbuhan Luas Daun Bibit $\left(\mathrm{cm}^{2}\right)$} \\
\hline & \multicolumn{2}{|c|}{ Bibit Umur 0-10 HST } & \multicolumn{2}{|c|}{ Bibit Umur 10-20 HST } \\
\hline & $\begin{array}{c}\text { Penambahan } \\
\text { Luas Daun }\end{array}$ & Luas Daun & $\begin{array}{c}\text { Penambahan } \\
\text { Luas Daun }\end{array}$ & Luas Daun \\
\hline $\mathrm{P}_{1}\left(20\right.$ ton $\left.\mathrm{ha}^{-1}\right)$ & 3,47 & 12,77 & 5,88 & 18,65 \\
\hline $\mathrm{P}_{2}\left(30\right.$ ton $\left.\mathrm{ha}^{-1}\right)$ & 6,09 & 15,39 & 9,40 & 24,79 \\
\hline $\mathrm{P}_{3}\left(40\right.$ ton $\left.\mathrm{ha}^{-1}\right)$ & 11,59 & 20,89 & 12,38 & 33,27 \\
\hline
\end{tabular}

Dinamika pertumbuhan jumlah daun, apabila dicermati berdasarkan Tabel 1 dan 2 tersebut juga menunjukkan bahwa peningkatan jumlah daun diikuti dengan peningkatan pertumbuhan luas daun bibit. Semakin meningkatnya umur bibit sampai 10 dan 20 HST maka semakin bertambah luas daun bibit stek pucuk stevia yaitu selama 10 hari ditanam maka bertambah luas daunnya mencapai 3,47 sampai $11,59 \mathrm{~cm}^{2}$ per bibit sehingga luas daunnya dari semula rata-ratanya $9,30 \mathrm{~cm}^{2}$ per stek awal ditanam menjadi antara 12,77 sampai $20,89 \mathrm{~cm}^{2}$ per bibit akibat pemberian pupuk kandang di tanah gambut. Begitu juga saat bibit mencapai umur 20 HST maka juga terjadi penambahan kembali luas daun bibit mencapai 5,88 sampai $12,38 \mathrm{~cm}^{2}$ per bibit sehingga luas daunnya menjadi antara 18,65 sampai $33,27 \mathrm{~cm}^{2}$ per bibit akibat pemberian pupuk kandang di tanah gambut
Dinamika peningkatan pertumbuhan daun bibit stek pucuk stevia tersebut dikarenakan stek mendapatkan dukungan pertumbuhan dari bahan tanam masing-masing stek maupun dukungan media tanam tanah gambut yang sudah membaik kesuburannya akibat diberikan pupuk kandang kotoran ayam sehingga secara morfologis dan fisiologis menjadi terpacu tumbuhnya stek pucuk stevia dan pertumbuhan daunnya. Pengaruh secara langsung dan tak langsung dari pupuk kandang menunjukkan peran yang baik dari pemberian pupuk kandang kotoran ayam memberikan peningkatan pertumbuhan bibit stek pucuk stevia khususnya terhadap jumlah daun dan luas daun. Adanya peningkatan pertumbuhan disebabkan pemupukan kotoran ayam mulai dosis 20 ton ha ${ }^{-1}$ sampai 40 ton $\mathrm{ha}^{-1}$ mampu memberikan perbaikan sifat-sifat fisika, kimia, dan biologis tanah gambut sebagai media tanam. Ini 
sesuai dengan keuntungan utama penggunaan jenis pupuk kandang kotoran ayam yaitu sebagai sumber unsur hara bagi tanaman yang dapat memperbaiki kesuburan tanahnya terhadap sifat kimia, fisika, dan biologi tanah (Hartatik dan Widowati, 2006).

Pertumbuhan bibit stek pucuk stevia berupa pertumbuhan penambahan jumlah daun dan luas daun diduga telah dimulai saat bibit selama 10 hari pertama setelah ditanam. Hal ini diduga bibit stek mengalami pertumbuhan stek dengan bentuk pertumbuhan akar dan daun stek, sehingga memanfaatkan unsur hara dari media tanah gambut dan digunakan untuk pertumbuhan seluruh organ stek pucuk stevia yang ditanam. Pemanfaatan unsur hara tersebut tentunya dilakukan oleh perakaran, batang dan daun bibit stek stevia sejak beberapa hari setelah ditanam. Hal ini sesuai dengan penjelasan Sumaryono dan Sinta (2008) yang menjelaskan bahwa bibit stek stevia biasanya sudah mempunyai pertumbuhan perakaran mulai muncul pada umur $3-5$ hari setelah stek ditanam. Saat perakaran muncul dan berkembang merupakan upaya awal pemanfaatan unsur hara yang diserap melalui akar dari media tanamnya.

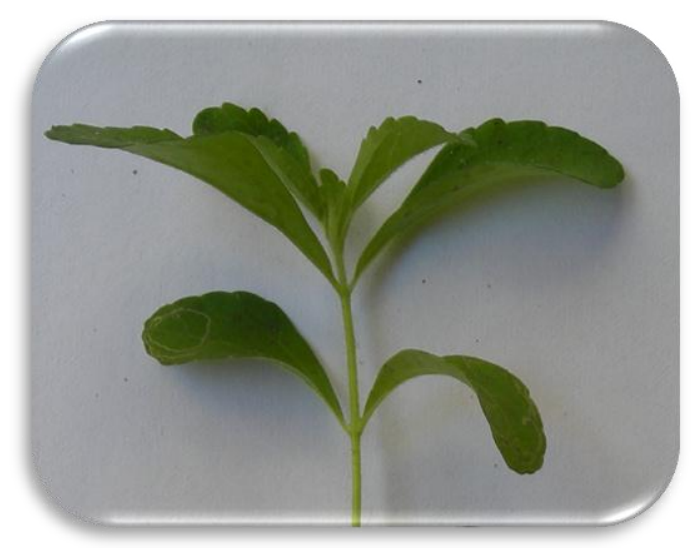

Gambar 1. Bahan tanam stek pucuk stevia
Penggunaan pupuk kandang kotoran ayam dalam mendukung pertumbuhan bibit stek pucuk stevia ini menunjukkan bahwa ada kesesuaian penggunaan pupuk kandang sebagai pupuk yang cocok digunakan saat berbudidaya tanaman stevia di tanah gambut. Hal ini diakibatkan sifat dari pupuk kandang kotoran ayam yang memiliki sifat sebagai pupuk panas, pupuk campuran kotoran padat dan cair, dan pupuk yang kandungan haranya relatif tinggi sehingga cepat melapuk dalam tanah dan menyediakan unsur hara bagi tanaman (Sutedjo, 1995). Selain itu dalam pupuk kandang terkadang tercampur sisa makanan ayam dan bahan alas kandang yang juga menyumbangkan tambahan hara ke dalam pupuk kandang (Widowati et al., 2005; Hartatik dan Widowati, 2006).

Semakin banyaknya kandungan hara pada pupuk kandang kotoran ayam (unsur N, P, K, Ca, dan $\mathrm{Mg}$ ) yang relatif tinggi makin mendukung pertumbuhan stek pucuk stevia. Kondisi ini terlihat dari dinamika pertumbuhan bibit stek pucuk stevia yang semula ditanam dengan kondisi 3 ruas ( 6 helai daun) mengalami pertumbuhan daun yang baik selama umur $10 \mathrm{HST}$ sampai $20 \mathrm{HST}$ di pembibitan digambarkan Gambar 1, 2, 3, dan 4.

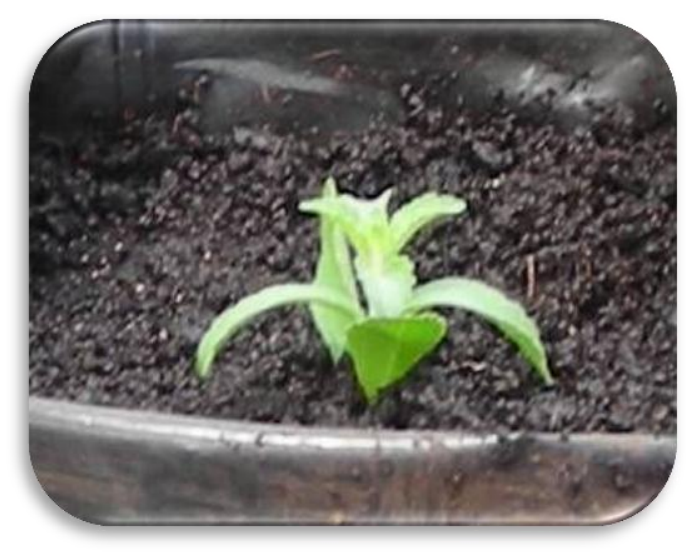

Gambar 2. Stek pucuk stevia yang ditanam 


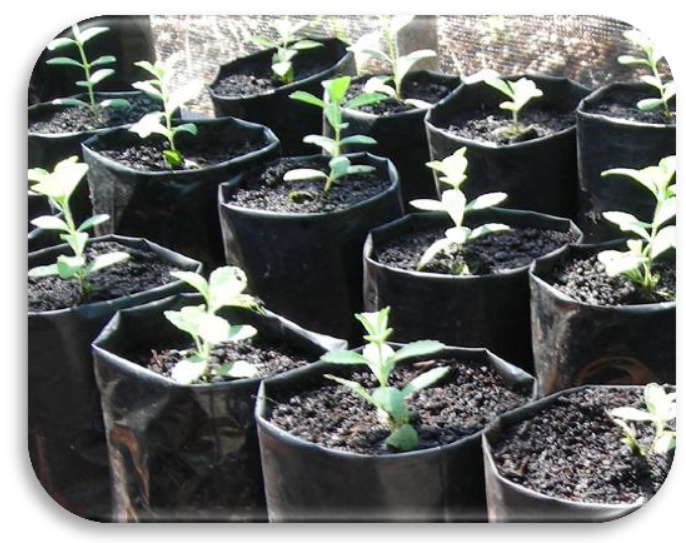

Gambar 3. Bibit stek pucuk stevia umur 10 HST

Pertumbuhan bibit stek pucuk stevia yang baik tersebut sesuai dengan yang dinyatakan Sumaryono dan Sinta (2008) menjelaskan bahwa bibit stek pucuk stevia yang sudah berumur sekitar 3 minggu biasanya sudah menunjukkan pertumbuhan bibit yang telah membentuk perakaran yang baik dengan tinggi tunas sekitar $10 \mathrm{~cm}$ dan dengan peningkatan penambahan 2 sampai 3 pasang daun baru. Seteleh berumur 3 minggu bibit stek pucuk stevia dalam pembibitan tersebut siap digunakan untuk ditanam di lapang.

\section{KESIMPULAN DAN SARAN}

\section{Kesimpulan}

Penelitian ini menghasilkan kesimpulan:

a. Daun stek pucuk stevia mampu tumbuh dengan baik pada umur bibit 10 dan 20 hari setelah tanam (HST) dengan menggunakan media tanam tanah gambut.

b. Pemberian pupuk kandang kotoran ayam dosis 20 ton ha ${ }^{-1}$ sampai 40 ton ha ${ }^{-1}$ mampu mendukung peningkatan dinamika pertumbuhan daun (jumlah daun dan luas

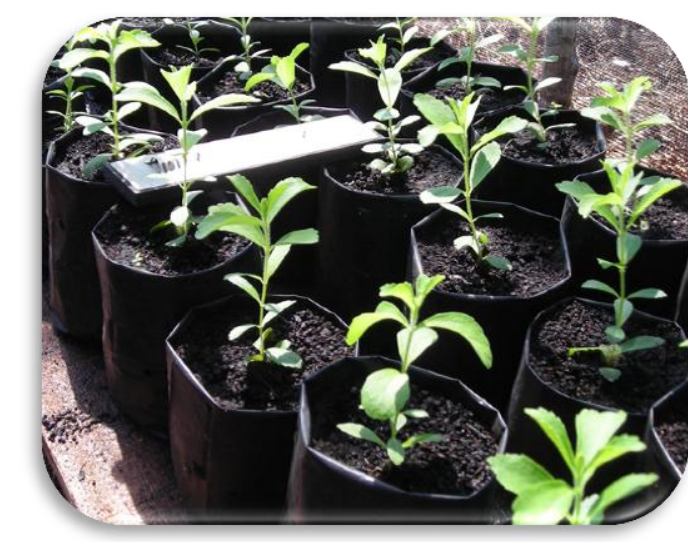

Gambar 4. Bibit stek pucuk stevia umur 10 HST

daun) bibit stek pucuk stevia pada umur 10 dan 20 HST pada tanah gambut.

\section{Saran}

Hasil penelitian ini masih sebatas pencermatan terhadap peningkatan jumlah daun dan luas daun stek pucuk stevia di pembibitan, sehingga memerlukan penelitian lanjutan secara detail tentang dinamika nisbah berat daun dan luas daun spesifik bibit stek pucuk stevia.

\section{UCAPAN TERIMA KASIH}

Ucapan terima kasih disampaikan kepada Ketua Program Studi dan mahasiswa di Program Studi Agroteknologi Fakultas Pertanian Universitas Muhammadiyah Palangkaraya yang terlibat bersama dalam kegiatan praktikum dan kegiatan penelitian bersama. Terimakasih juga disampaikan kepada LP2M Universitas Muhammadiyah Palangkaraya yang telah memfasilitasi kegiatan penelitian dan administrasi penelitian ini pada Tahun 2017. 


\section{DAFTAR PUSTAKA}

Ariyanti, F., 2017. Produksi Seret, RI Impor Gula 1,3 Juta Ton di 2017. Liputan6.com. http://bisnis.liputan6.com/read/2890396/pro duksi-seret-ri-impor-gula-13-juta-ton-di-

2017. Diakses pada tanggal 12 Juni 2017.

Atikah, T. A., 2004. Pengaruh Bobot Isi Gambut dan Dosis Pupuk Kandang Kotoran Ayam Terhadap Pertumbuhan Tanaman Jagung Manis (Zea mays saccharata Sturt). Laporan Hasil Penelitian Kopertis Wilayah XI Kalimantan. Banjarmasin.

BPS, 2010. Kota Palangka Raya Dalam Angka 2010. Badan Pusat Statistik Kota Palangka Raya. Palangka Raya. ISSN 0215-5990

Direktorat Jenderal Perkebunan Kementerian Pertanian, 2010. Untuk Mewujudkan Swasembada Gula, Pemerintah Akan Melakukan Revitalisasi Pabrik Gula. Direktorat Jenderal Perkebunan Kementerian Pertanian. http://ditjenbun.deptan.go.id/index.php?opti on=com_content\&view $=$ article \& id=179:untuk-mewujudkan-swasembadagula-pemerintah-akan-melakukanrevitalisasi-pabrik-gula\&catid=36:news. Diakses tanggal 2 Januari 2011.

Hartatik, W. dan L.R. Widowati, 2006. Pupuk Organik dan Pupuk Hayati. Ed.: R.D.M. Simanungkalit, D.A. Suriadikarta, R. Saraswati, D. Setyorini, dan W. Hartatik. Prosiding. Balai Besar Litbang Sumberdaya Lahan Pertanian. Badan Penelitian dan Pengembangan Pertanian. Bogor.

llyas, R., 2003. Stevia. InfoPOM. Badan Pengawas Obat dan Makanan Republik Indonesia. Volume : IV Edisi 11: Nopember 2003. 1-3

Rukmana, H. R., 2007. Budidaya Stevia : Bahan Pembuatan Pemanis Alami. Cetakan Ke-5. Kanisius. Yogyakarta.
Sumaryono dan M.M. Sinta. 2008. Petunjuk Teknis Budidaya Tanaman Stevia. Pusat Penelitian Bioteknologi dan Bioindustri Indonesia. Bogor. http://iribb.org/images/stories/produk/Petunj uk\%20Teknis\%20Budidaya\%20Stevia.pdf.

Diakses pada tanggal 12 Juni 2017.

Susilo, D.E.H., 2012. Studi Budidaya Stevia (Stevia rebaudiana Bertoni M.) Sebagai Bahan Dasar Gula Pada Tanah Gambut di Kota Palangka Raya. Anterior Jurnal. Vol.11 No.2 Juni 2012 : $6-11$.

Susilo, D.E.H., J. Hadie dan R. Zulhidiani, 2012. Dinamika Tumbuh Stek Pucuk Stevia Menggunakan Naungan dan Pupuk Kotoran Ayam pada Tanah Gambut Pedalaman. Anterior Jurnal. Vol.12 No.1 Desember $2012: 1-12$.

Sutedjo, M. M., 1995. Pupuk dan Cara Pemupukan. Rineka Cipta. Jakarta.

Triyatna, S.O., 2012. Produksi Gula Hanya 60\% Kebutuhan.

http://bisniskeuangan.kompas.com/read/20 12/07/28/12445943/Produksi.Gula.Hanya.6 0 .Persen.Kebutuhan. Diakses tanggal 30 Juli 2012

Widowati, L.R., Sriwidati, U. Jaenudin, dan W. Hartatik, 2005. Pengaruh Kompos Pupuk Organik yang Diperkaya dengan Bahan Mineral dan Pupuk Hayati terhadap SifatSifat Tanah, Serapan Hara dan Produksi Sayuran Organik. Laporan Proyek Penelitian Program Pengembangan Agribisnis. Balai Penelitian Tanah.

Winarno, A. 2017. 2017, Pemerintah akan Impor Gula 1 Juta Ton Lebih. Kompas.com. http://regional.kompas.com/read/2017/03/1 7/00244031/.2017.pemerintah.akan.impor.g ula.1.juta.ton.lebih. Diakses pada tanggal 12 Juni 2017 